\title{
FIRST OBSERVATIONS ON THE TRANSITION FROM THE LATE BRONZE AGE TO THE EARLY IRON AGE IN TISNA, WESTERN ANATOLIA
}

\section{TISNA'DA GEÇ TUNÇ ÇAĞI'NDAN ERKEN DEMIR ÇAĞI'NA GEÇIŞTE ILK GÖZLEMLER}

\author{
Makale Bilgisi Article Info \\ Başvuru: 13 Temmuz 2020 Received: July 13, 2020 \\ Hakem Değerlendirmesi: 12 Ekim 2020 Peer Review: October 12, 2020 \\ Kabul: 01 Aralık 2020 Accepted: December 01, 2020
}

DOI : 10.22520/tubaar2020.27.007

\section{Barıș GÜR *}

\section{ABSTRACT}

Recent surveys conducted in Sarıkale Tepe and Kocakale Tepe in 2018 and 2019 yielded some findings that shed light on the transition from the Late Bronze Age to the Early Iron Age in the Aeolis region. This study examines and broadly evaluates a bronze fragment belonging to a curved knife, pottery that has stylistically similar examples found in the Late Bronze Age layers of the city of Troy, gray ware which has an important place in the local tradition of the region, and a pendent semi-circle pottery sherd, found during the course of these seasons. The reflections of the external influences in Northern Aeolis, the continuation of the local traditions in the Early Iron Age and the existence of the Aegean origin influences in the beginning of the first millennium $\mathrm{BC}$ were examined.

As a result, the mentioned finds in Tisna reveal supportive results in addition to the new and known ones regarding the transition from the Late Bronze Age to the Early Iron Age in Aeolis. It is thought that the archaeological excavations to be carried out in Tisna in the coming years will provide new evidence to support these findings.

Keywords: Tisna, Late Bronze Age, Iron Age, Western Anatolia.

\footnotetext{
Doç. Dr., Dokuz Eylül Üniversitesi Edebiyat Fakültesi, Müzecilik Bölümü, Tınaztepe Kampüsü, Buca-İZMİR, e-posta: baris.gur@deu.edu.tr. 


\section{ÖZET}

2018 ve 2019 yıllarında Sarıkale Tepe ve Kocakale Tepe'de gerçekleştirilen yüzey araştırmaları, Aeolis bölgesinde Geç Tunç Çağı'ndan Erken Demir Çağı'na geçişe 1şık tutan bazı bulguları ortaya çıkarmıştır. Bu çalışmada, Troya kentinin Geç Tunç Çağı tabakalarında ele geçen stilistik olarak benzer örneklere sahip seramikler, kavisli bir bıçağa ait tunçtan bir parça, bölgenin yerel geleneğinde önemli bir yere sahip olan Gri seramikler ve "pendent semi-circle" bezemeli bir skyphos parçası incelenerek, genel olarak değerlendirilmiştir. Çalışma içerisinde ana hatlarıyla Kuzey Aeolis’teki dış etkilerin yansımaları, Erken Demir Çağı'nda yerel geleneklerin sürekliliği ve MÖ Birinci binyılın başlarında Ege kökenli etkilerin varlığı gibi başlıca konular incelenmiştir.

Sonuç olarak, Tisna'daki yüzey araştırmaları sırasında elde edilen söz konusu buluntular, Aiolis’te Geç Tunç Çă̆ı'ndan Erken Demir Çă̆ı'na geçişle ilgili yeni ve bilinenlere ek olarak, destekleyici sonuçlar ortaya koymaktadır. Bununla birlikte önümüzdeki yıllarda Tisna' da yapılacak arkeolojik kazıların bu bulguları destekleyecek yeni kanıtlar sağlayacağ1 düşünülmektedir.

Anahtar Kelimeler: Tisna, Geç Tunç Çă̆ı, Demir Çağı, Batı Anadolu. 


\section{INTRODUCTION}

Recent surveys conducted in Sarikale Tepe and Kocakale Tepe in 2018 and 2019 yielded some findings that shed light on the transition from the Late Bronze Age to the Early Iron Age in the Aeolis region ${ }^{1}$ (Fig. 1a-b). This study examines and broadly evaluates a bronze fragment belonging to a curved knife, pottery that has stylistically similar examples found in the Late Bronze Age layers of the city of Troy, gray ware-which has an important place in the local tradition of the region, and a pendent semi-circle pottery sherd, found during the course of these seasons. The reflections of the external influences in Northern Aeolis, the continuation of the local traditions in the Early Iron Age and the existence of the Aegean origin influences in the beginning of the first millennium $\mathrm{BC}$ will be examined.

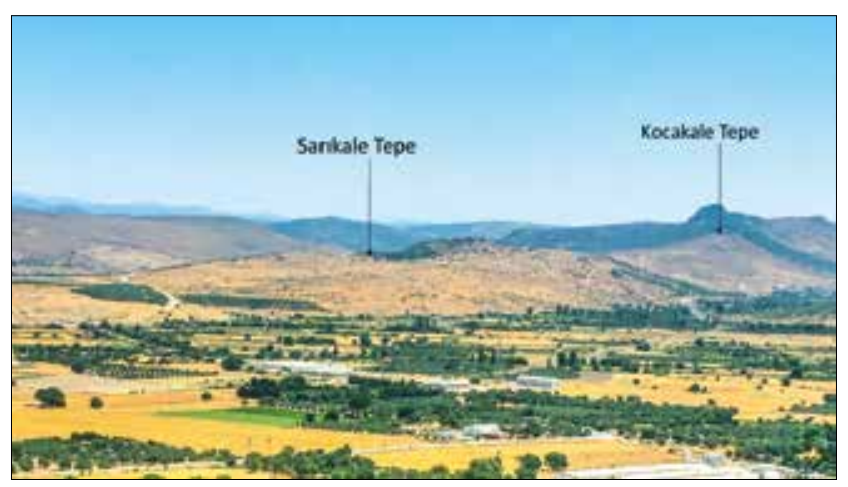

Figure 1a: Sarıkale Tepe and Kocakale Tepe / Sarlkale Tepe ve Kocakale Tepe

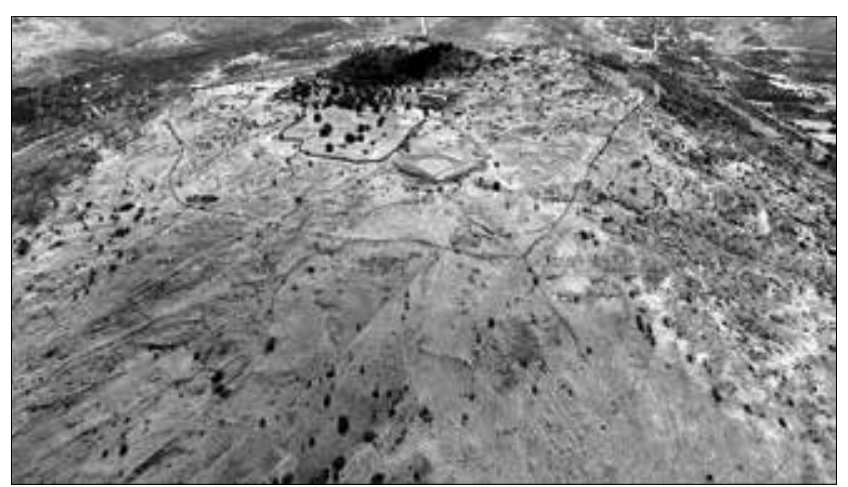

Figure 1b: Sarıkale Tepe / Sarıkale Tepe

\section{Sarıkale Tepe and Kocakale Tepe (Tisna)}

Our knowledge is very limited in terms of ancient texts about Tisna, which is situated within the borders of the Uzunhasanlar Neighborhood of the Aliağa District,

\footnotetext{
I would like to thank Assoc.Prof.Dr. Emre Erdan, the President of the Archaeological Survey of Tisna Ancient City, who allowed me to study the survey material on Tisna.
}

Izmir. Although information about the city mentioned by Titanus in Plinius' Naturalis Historia is limited in a literary sense, the archaeological findings conveyed by researchers from the $19^{\text {th }}$ century are substantial. The city was first discovered by the French traveler Guichon, who was traveling in the region ${ }^{2}$, and it was also evaluated within the framework of short-term observations by important scientists such as Sayce ${ }^{3}$, Diest ${ }^{4}$, Schuchhardt ${ }^{5}$ and Conze ${ }^{6}$.

The surveys that were started in 2018 by a team which included myself, have shown that Tisna is located on two separate hills in east-west direction called Kocakale Tepe and Sarıkale Tepe today. As a result of the studies carried out, it has been determined that Sarıkale Tepe is the main settlement area?.

The studies carried out in Tisna so far have provided detailed information especially about the first millennium $\mathrm{BC}^{8}$. However, it is possible to mention the findings that show that the settlement can be dated to an earlier period. First of all, it should be noted that the possible traces referring to the Late Bronze Age, which are on the city walls of the acropolis at Kocakale Tepe ${ }^{9}$, makes an impression that corresponds with the settlement system of the Late Bronze Age defense system in Western Anatolia ${ }^{10}$. Apart from this, pottery from Sarkale Tepe yields insights that further add to earlier studies that suggest Late Bronze Age settlement on the site. Pottery from the second millennium $\mathrm{BC}$ is known to have been found in Tisna, which was built on Kocakale Tepe and Sarıkale Tepe. ${ }^{11}$

\section{Finds From Tisna}

Archaeological surveys in Tisna were conducted for the first time in 2018 and continued in 2019. As a result of the research along the Titnaios, which is known as Güzelhisar stream today, important findings regarding settlement in the inner parts of the Aeolis region were encountered (Fig. 2) ${ }^{12}$.

Reinach 1885: 107-109 (5.72-3).

Sayce 1882: 221.

Diest 1889: 32-33.

5 Schuchhardt 1887: 1213.

6 Conze 1910.

Erdan 2019: 3.

8 Erdan 2019: 37.

9 In addition, during the researches carried out during the 2019 surveys, cyclopean walls were encountered in Sarıkale Tepe, which can be dated to the second millennium BC. (Personal communication with Emre Erdan)

10 One of the best known examples in this subject is Bademgediği Tepe (Meriç/Öz 2015). For the defensive architecture in Western Anatolia in the Late Bronze Age. See. Gür 2014: 206208.

11 Erdan/Gür 2018: 405, fn. 75

12 Erdan 2019: 37-38. 


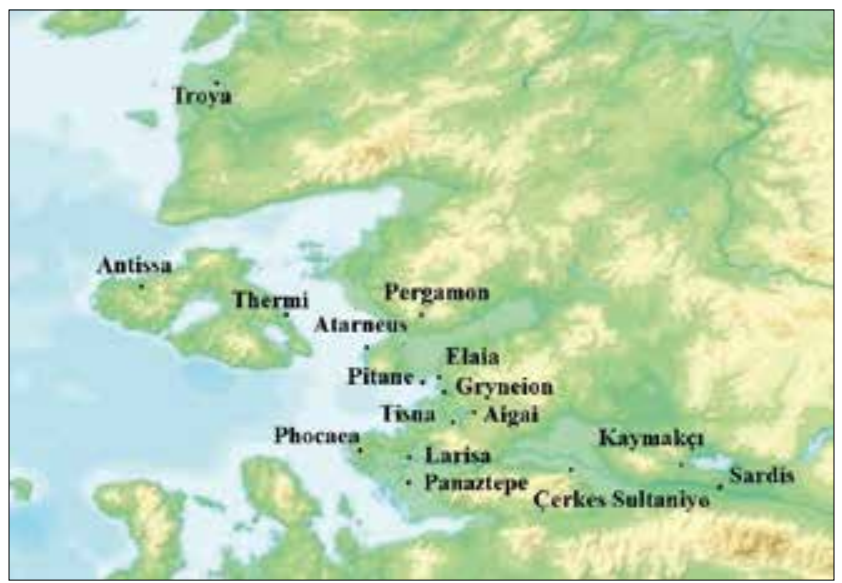

Figure 2: The map involving the settlements mentioned in the study / Çalışmada adı geçen yerleşimleri içeren harita

The first of the finds subject to the study (No. 1) is a sherd of gritty ware (Inv. No. TIS 1887). Its height is $11.2 \mathrm{~cm}$ and its width is $7 \mathrm{~cm}$. It has a reddish brown clay (2.5 YR 5/4), with stone additives and blackness on the surface related to cooking. Applique nozzles, which are characteristic of this type of pottery, are also observed on the surface ${ }^{13}$ (Fig. 3).

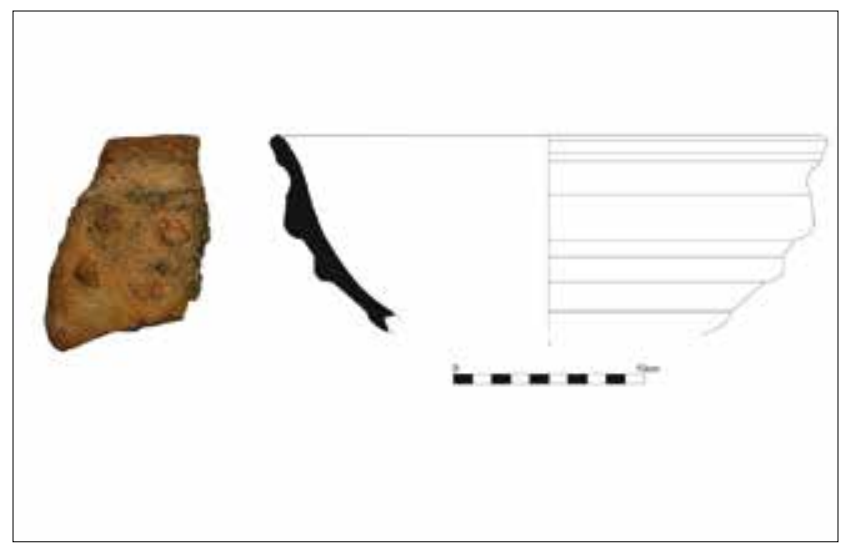

Figure 3: A fragment of gritty ware (No. 1) and its drawing (Courtesy of the headship of Tisna archaeological survey) / Gritty ware parçası (No. 1) ve çizimi (Tisna arkeolojik yüzey araştırması başkanlığının izniyle)

This type of pottery in question is found in the phases of Troy VI-VII and is named as gritty ware. ${ }^{14}$ The presence of gritty ware in the settlement suggests that Sarıkale Tepe was settled during the Late Bronze Age, as well as suggesting that it may be connected with different settlements in the wider region. When the main function of the form is evaluated, it is possible to say that gritty ware played an important role in daily life as a cooking pot in Troy ${ }^{15}$. This type of pottery, which was used as

13 Erdan 2019: 38, Cat. No. 2.

14 Erdan 2019: 38.

15 Blegen et. al. 1958: 24; Rigter 2013: 79, Taf. 30.3-6; Pavuk 2014: Taf. 51. İ8.429.4; Aslan 2011: 400-402 a cooking pot ${ }^{16}$ for a period of more than four hundred years in Troy, was wheel-made.

The second find (No. 2) belongs to a knobbed ware vessel (Inv. No. TIS 18.178). Its height is $10.6 \mathrm{~cm}$ and its width is $15.8 \mathrm{~cm}$. It has a reddish brown clay ( $2.5 \mathrm{YR}$ $6 / 4$ ), with stone additives and mica. It has a pointed knob on its surface ${ }^{17}$ (Fig. 4).

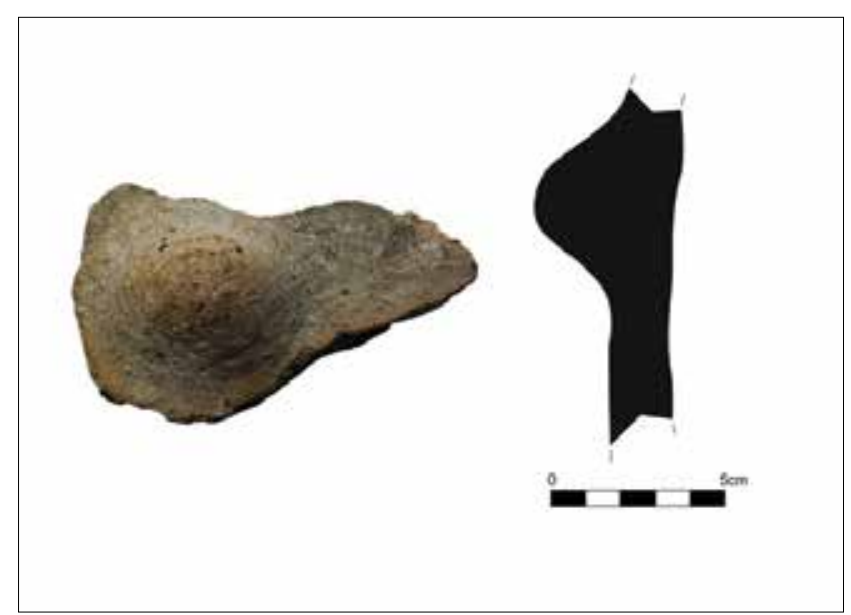

Figure 4: Knobbed ware pottery fragment (No. 2) and its drawing (Courtesy of the headship of Tisna archaeological survey) / Knobbed ware parçası (No. 2) ve çizimi (Tisna arkeolojik yüzey araştırması başkanlığının izniyle)

The third find (No. 3) belongs to an another sherd of knobbed ware (Inv. No. TIS 18.219). Its height is $8.4 \mathrm{~cm}$ and its width is $5.3 \mathrm{~cm}$. It has a reddish brown clay (5YR $6 / 4$ ), with stone additives, lime and mica. It has a circular knob on its surface ${ }^{18}$ (Fig. 5).

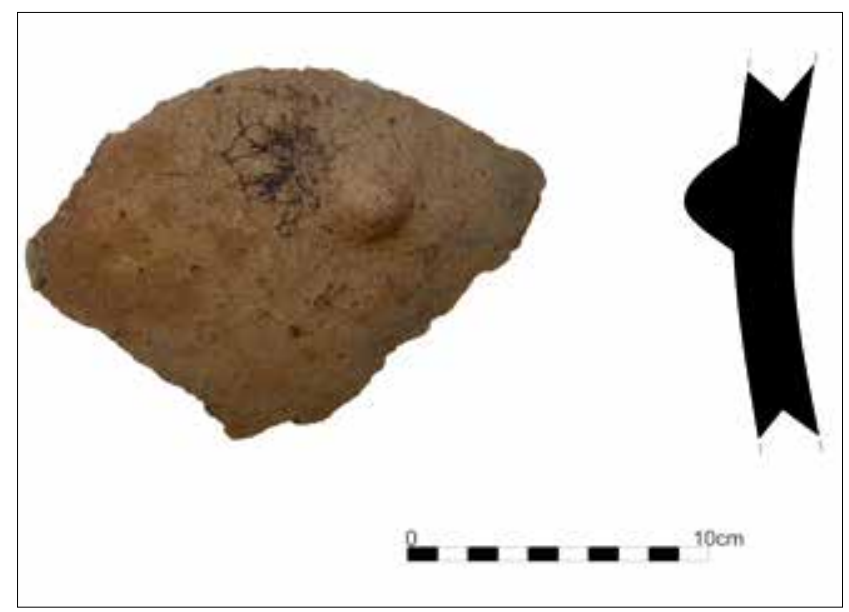

Figure 5: Knobbed ware pottery fragment (No. 3) and its drawing (Courtesy of the headship of Tisna archaeological survey) / Knobbed ware parçası (No. 3) ve çizimi (Tisna arkeolojik yüzey araştırması başkanlığının izniyle)

\footnotetext{
16 Aslan 2015: 187.

17 Erdan 2019: 58, Cat. No. 3.

18 Erdan 2019: 58, Cat. No. 4.
} 
Another type of coarse pottery found in Tisna, such as gritty ware, which was defined by Blegen in coarse production goods, are knobbed ware sherds ${ }^{19}$, which are also considered in the handmade pottery group ${ }^{20}$. Analogues of two separate sherds with pale reddish brown clay and knobbed surfaces began to be obtained in the Aegean world with the phase of Troy VIIb2 corresponding to the LH IIIC period ${ }^{21}$. Counterparts of knobbed ware are known from Southeastern Europe, Greece, and Thrace ${ }^{22}$. The knobs in both pottery sherds in Tisna are seen on handmade pottery in many different regions. Of these, it is possible to count Menelaion ${ }^{23}$ and Western Macedonia ${ }^{24}$ in Greece primarily.

All in all, the spread of knobbed ware and its presence in Troy VIIb2 are evaluated in a migration phenomenon ${ }^{25}$. In the same period, as the knobbed ware and its close parallels spread throughout the Western Anatolia ${ }^{26}$, this spread includes the Phrygian lands - Gordion ${ }^{27}$. The presence of a migration from the Balkans before Troy can be traced through the pottery in Taşlıcabayır ${ }^{28}$, İstanbul Çatalca $^{29}$ and then Maydos Kilisetepe ${ }^{30}$.

It is not possible to make suggestions about the gritty ware and knobbed ware sherds, on whether or not they were produced in Troy or locally. Yet, the clay analyses, even in Troy VIIb2, reveal that not every knobbed ware is local production $^{31}$. According to a study, analogues of the knobbed ware in Troy was found in Southern Bulgaria as a result of chemical analyses ${ }^{32}$. This incident sets out that knobbed ware was produced and used in different settlements throughout a wide region from the Balkans to Troy.

Another type of pottery unearthed in Tisna is Gray ware. The fourth find (No. 4) is a sherd from this group (Inv. No. TIS 19.264). Its height is $3.2 \mathrm{~cm}$ and its width is $3.5 \mathrm{~cm}$. It has a light gray clay (Gley $17 / \mathrm{N})$, with stone additives,

19 Knobbed ware is defined by Lis (2009: 152) in the West Anatolian Handmade Pottery group in relation to Handmade Burnished Ware.

20 Handmade pottery was first identified as buckelkeramik by Heinrich Schliemann through finds from Troy excavations, and later named Carl Blegen as knobbed ware and coarse ware. From the finds in Greece, the definition of Barbarian pottery was brought to the literature by Catling and this definition was continued by Karageorghis. Guzowska et al. 2003: 234.

21 Rutter 1975: 27.

22 Sams 1992: 57; Pinter 2005: 18, passim.

23 Catling/Catling 1981: P1. 5.7-11.

24 Romiopoulou 1971: 358, P1. 59.34.

25 Özdoğan 2011: 673; Bozhinova 2012: 57; Hnila 2012: 216.

26 Beksaç 2001: 114-115; Vassileva 2005: 230.

27 Vassileva 2005: 227, passim.

28 Özdoğan 1987: 5-39; 1993, 162.

29 Aydıngün/Aydıngün 2013: 67-68.

30 Sazc1 2012: 17-18, Fig. 4.

31 Guzowska et al. 2003: 248.

32 Laszló 1996-1997: 55. lime, sand and chamotte, exterior dark gray slip (Gley 1 4/N), interior brown slip (7.5 YR 4/2). ${ }^{33}$ (Fig. 6).

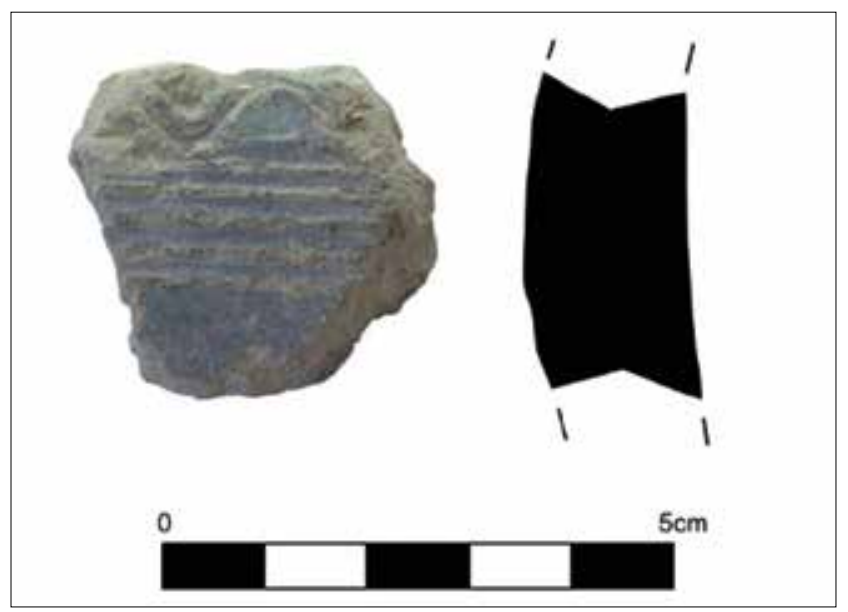

Figure 6: A gray ware sherd (No. 4) and its drawing (Courtesy of the headship of Tisna archaeological survey) / Gri seramik parçası (No. 4) ve çizimi (Tisna arkeolojik yüzey araştırması başkanlığının izniyle)

The fifth find (No. 5) is a gray ware sherd (Inv. No. TIS 19.167). Its height is $3.1 \mathrm{~cm}$ and its width is $6.3 \mathrm{~cm}$. It has a light gray clay (5 YR 7/1), with stone additives, lime, sand and chamotte, pinkish gray slip (7.5 YR 7/2). ${ }^{34}$ (Fig. 7).

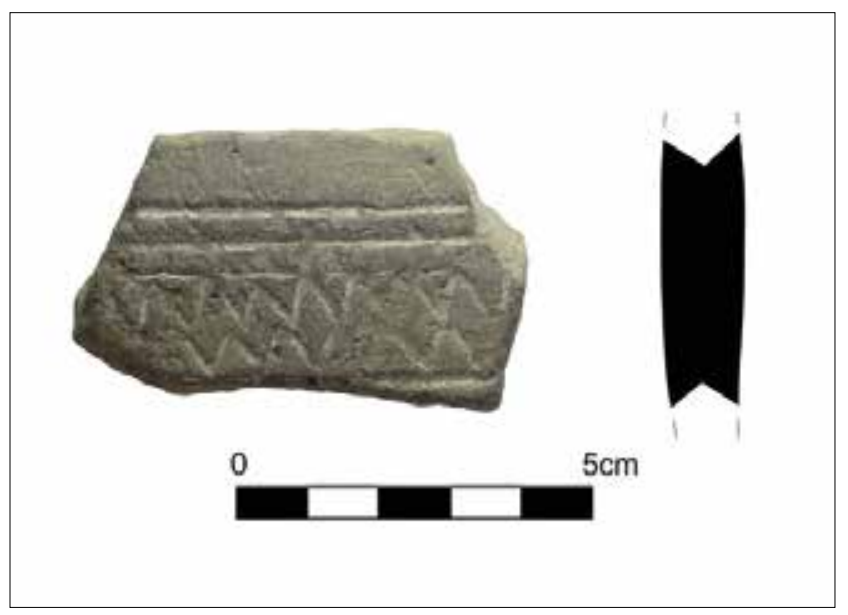

Figure 7: A gray ware sherd (No. 5) and its drawing (Courtesy of the headship of Tisna archaeological survey) / Gri seramik parçası (No. 5) ve çizimi (Tisna arkeolojik yüzey araştırması başkanlığının izniyle)

The sixth find (No. 6) is a gray ware sherd (Inv. No. TIS 19.166). Its height is $3.1 \mathrm{~cm}$ and its width is $7.8 \mathrm{~cm}$. It has a light gray clay (GLEY $17 / \mathrm{N}$ ), with stone additives and lime, light bluish gray slip (GLEY 2 8/1 /10B). ${ }^{35}$ (Fig. 8).

\footnotetext{
33 Erdan 2019: 60, Cat. No. 8.

34 Erdan 2019: 60, Cat. No. 7.

35 Erdan 2019: 59, Cat. No. 6.
} 


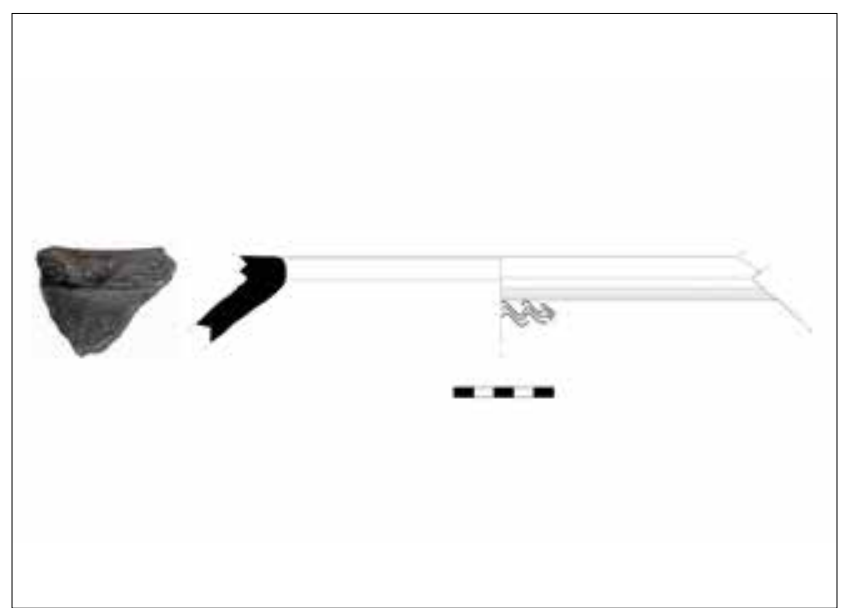

Figure 8: A gray ware sherd (No. 6) and its drawing (Courtesy of the headship of Tisna archaeological survey) / Gri seramik parçası (No. 6) ve çizimi (Tisna arkeolojik yüzey araştırması başkanlığının izniyle)

The sherds found in the Tisna survey are in matte gray or light gray and gray tones. There are zigzag and wave motifs on the gray ware sherds as incised. Gray ware is obtained in many settlements starting from Troy ${ }^{36}$ in the north, along Lesbos ${ }^{37}$ and Western Anatolian coasts ${ }^{38}$. In the use of gray ware, it is visible that the main settlements in the Aeolis region are Panaztepe and Larisa ${ }^{39}$. Similar wavy decorations on the gray ware are dated to the Late Bronze Age in Troy VI ${ }^{40}$, Larisa ${ }^{41}$, Cyprus and Philistine ${ }^{42}$, and to the Early Iron Age in Mytilene ${ }^{43}$, Lesbos-Antissa ${ }^{44}$ and Phocaea ${ }^{45}$.

The seventh find (No. 7) is a skyphos sherd (Inv. No. TIS 18.156). Its height is $4 \mathrm{~cm}$ and its width is $6.7 \mathrm{~cm}$. It has a red clay (10 R 4/8), with stone additives, lime and mica, reddish yellow slip (2.5 YR 5/6), painted red (10 R 4/8), with pendent semi-circle motif.46 (Fig. 9).

The pottery sherd belongs to a "pendent semi-circle" skyphos unearthed during the survey in Tisna, and is an important find as it exhibits the continuity in the settlement from the Late Bronze Age to the Early Iron $\mathrm{Age}^{47}$. Skyphos with semicircular motifs depicted in the area between handles were first developed in and around

36 Blegen et. al. 1958: 21; Aslan 2019.

37 Bayne 2000: 205.

38 Aykurt 2008: 18-19.

39 Aykurt 2008: 18-19.

40 Allen 1991: 156, Fig. 15.1.

${ }^{41}$ Boehlau/Schefold 1942: Taf. 1.28-29; Bayne 2000: 88, Fig. 22.9-10

42 Allen 1991: 151; Pieniazek et al. 2018: 390, Fig. 22.

43 Bayne 2000: 211, Fig. 62.3.

44 Bayne 2000: 205, Fig. 59.5-6.

45 Bayne 2000: Fig. 51.7.

46 Erdan 2019: 61, Cat. No. 9.

47 Erdan 2019: 38, Cat. No. 9.

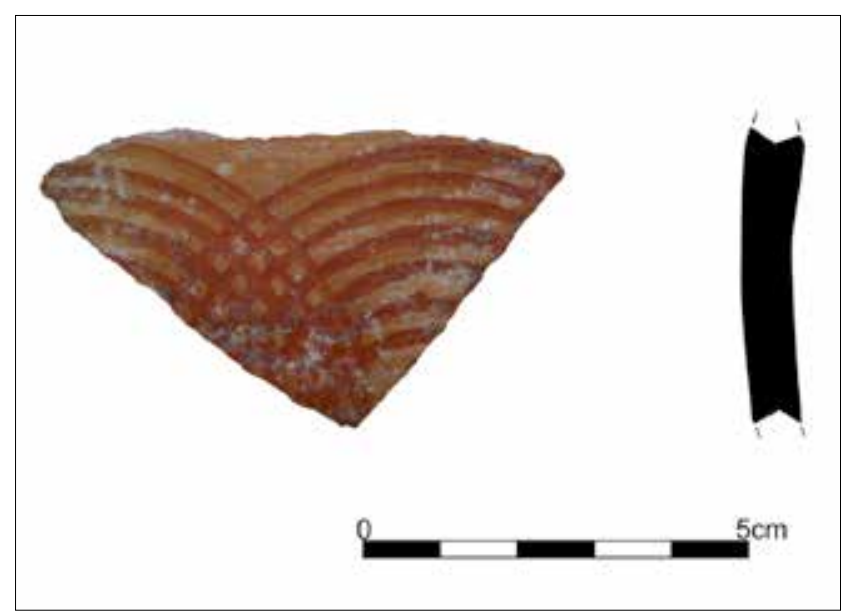

Figure 9: "pendent semi-circle" skyphos sherd (No. 7) and its drawing (Courtesy of the headship of Tisna archaeological survey) / "pendent semi-circle" skyphos parçası (No. 7) ve çizimi (Tisna arkeolojik yüzey araştırması başkanlığının izniyle)

Lefkandi ${ }^{48}$. Then it spread to the Thessalia Region and from there to the Northern Cycladic Islands ${ }^{49}$. Analogues of the reddish brown painted skyphos sherd on the ground with a slipped reddish yellow, clay in the same color were generally used from the Protogeometric period up to the Geometric period $^{50}$. It is possible to date the pottery sherd belonging to the "pendent semi-circle" skyphos found in Tisna to the Sub-Protogeometric period"

The eighth find (No. 8) is the knife fragment, which has a single cutting edge, has a curved form and is broken on both sides. Intense corrosion is observed on its surface and it is made of bronze. The fragment is $5.6 \mathrm{~cm}$ wide and $1.5 \mathrm{~cm} \mathrm{high}^{52}$ (Fig. 10a-b).

The most prominent feature of Aegean-type bronze cutting objects, such as knives and razors, is that they have a curved form in profile ${ }^{53}$. Although the curved form of the Aegean- type knives is obvious, it is possible to mention various types of production. Among them, the products in slightly curved form and the end-to-end productions are in majority. Sandars defines such examples from Diktaean Cave and from Tomb 49 in Mycenae as class 1b. The knives with a long and thin profile have one cutting edge e $^{54}$. Another knife from Ialysos in Rhodes ${ }^{55}$, Colophon ${ }^{56}$ and Siana group is in curved form ${ }^{57}$.

\footnotetext{
48 Lemos 2002: 44.

49 Coldstream 2003: 40.

50 Lemos 2002: 44; Dickinson 2007: Fig. 5.10.3,7; Verdan et al. 2014: 77, Fig. 2.

51 Erdan 2019: 61, Cat. No. 9.

52 Erdan 2019: 47, Cat. No. 93.

53 Alram-Stern/Jalkotzy 2006: 108, Cat. No. 9 pl. 23, pl. IX; Alram-Stern 2007: 16.

54 Sandars 1955: 178, Fig. 2.3-4.

55 Sandars 1963: 140, Pl. 27.56

56 Sandars 1963: 140, P1. 27.57

57 Sandars 1963: 140; Pl. 27.54.
} 


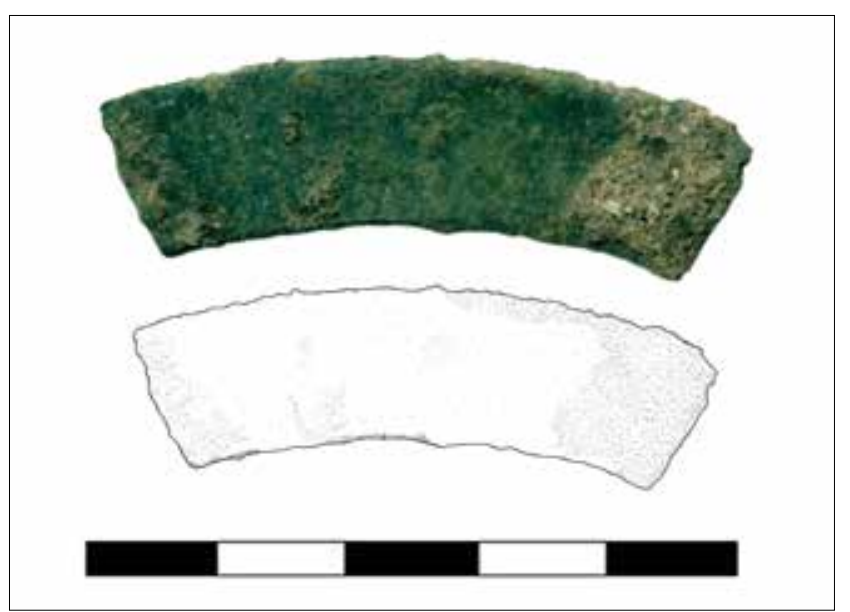

Figure 10a: The bronze curved knife fragment (No. 8) and its drawing (Courtesy of the headship of Tisna archaeological survey) / Tunçtan kavisli bıçak parçası (No. 8) ve çizimi (Tisna arkeolojik yüzey araştırması başkanlı̆̆ının izniyle)

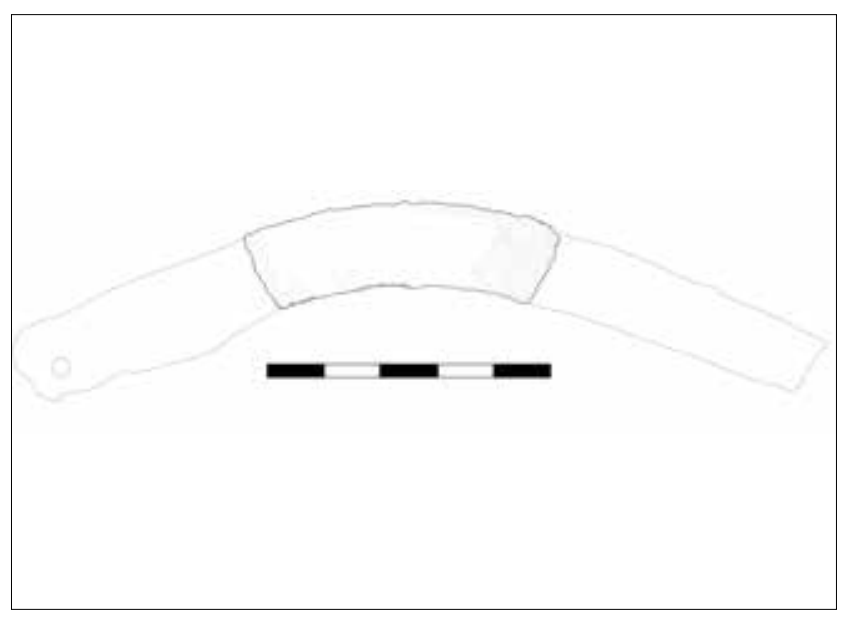

Figure 10b: Drawing of the likely integrated version of the bronze curved knife fragment / Tunçtan kavisli biçak parçasının muhtemel tüm halinin çizimi (Tisna arkeolojik yüzey araştırması başkanlığının izniyle)

Whereas in Western Anatolia, many thin, long, curved, thin-tipped knives were found in Panaztepe ${ }^{58}$. The handles of the knives have one or more rivets ${ }^{59}$. Similar ones were found in Uluburun Shipwreck ${ }^{60}$ and Sarımeşe Tepe ${ }^{61}$. In the altar of Klaros Apollon, the curved knives whose forms are thinned and thickened are dated to the end of the Mycenaean $\mathrm{era}^{62}$.

As the shorter bronze knives ${ }^{63}$ whose blind side is flat, the cutter edge is getting thinner while twisting are also found in Mycenaean tombs and settlements, shorter and thicker knives were also produced ${ }^{64}$. There are also examples

\footnotetext{
58 Ersoy 1988: P1. 7a

59 Erkanal 2018: Taf. 346, B13, AT3, Ğ17-20, BD6, X28.

60 Yalçın et al. 2006: 626, Cat. No. 175.

${ }^{61}$ Gencer 2016: 373-374, Res. 3-4

62 Verger 2014: 30, Fig. 15.1-2.

63 Paschalidis 2018: 309, Fig. 655; 323, Fig. 701.

${ }_{64}$ Paschalidis 2018: 330, Fig. 717; 331, Fig. 721.
}

where the Aegean-type knives approach a more convex and semicircular form. The form in question, which is called the sickle-like knife, is quite functional with its twisting feature.

Sickle-like knives became widespread in Mainland Greece, especially during the LH IIIC period. Three different knives from graves in Achaia Clauss are dated to LH IIIC Middle-Late phases ${ }^{65}$. One of them, with its curved form, is dated to the late stage of LH IIIC and is similar to the Tisna example ${ }^{66}$. A demonstrable analogue of the entire form of the fragment uncovered in Tisna was obtained within the context of settlement in Aigeira ${ }^{67}$, and it dates back to the LH IIIC period ${ }^{68}$ (Fig. 11). As bronze knives are often left as gifts to the dead in Mycenaean graves, it is observed that they were also found in settlements through the examples of Aigeria and Mycenae ${ }^{69}$.

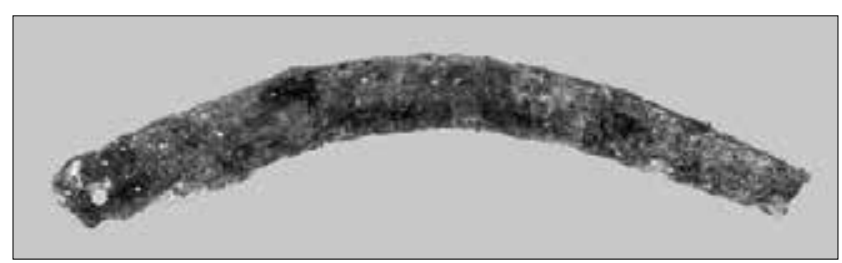

Figure 11: An Aegean-type curved knife from Aigeira (after Alram-Stern/Jalkotzy 2006, 108, Cat.no. 9 pl. 23, pl. IX; 2007, Fig.2.2) / Aigeira'dan Ege tipi kavisli bıçak

A group of knives from Aegina ${ }^{70}$ are either curved or sicklelike and dated to LH IIIB2-IIIC periods ${ }^{71}$. (Fig. 12)It is seen in some warrior graves in Greece that there are weapons such as swords and spearheads together with sickle-like knives $^{72}$. Similar sickles were found with LH IIIC pottery in Salamis $^{73}$ and Enkomi ${ }^{74}$ in Cyprus. In addition, bronze and iron curved knives used in weaving in the $9^{\text {th }}$ century $\mathrm{BC}$ in the city of Gordion in Anatolia were also found ${ }^{75}$.

Although previous studies have already indicated the presence of Late Bronze Age settlement and activity in this region, these finds are important in terms of showing the variety of objects in Tisna during the transition from Late Bronze Age to Early Iron Age.

65 Paschalidis 2018 330, Fig. 717; 331, Fig. 720.

66 Paschalidis/McGeorge 2009: 95, Fig. 13.

67 I would like to thank Prof. Eva Alram-Stern for allowing me to use the image of the knife from Aigeira in my essay.

68 Alram-Stern/Jalkotzy 2006: 108, Cat. No. 9 pl. 23, pl. IX; Alram-Stern 2007: 16.

69 Wace 1953: XLVIIIb.

70 I would like to thank Prof. Gauss for allowing me to use the image of the knives from Aegina in my essay.

71 Gauss 2007: 128, Abb. 18-22.

72 Petropoulos 2007: 262 Fig. 88.

73 Lolos 2003: 111, Fig. 19.

74 Catling 1964: 83, Fig. 8.1-2.

75 Burke 2005: 79, Fig. 6-9. 


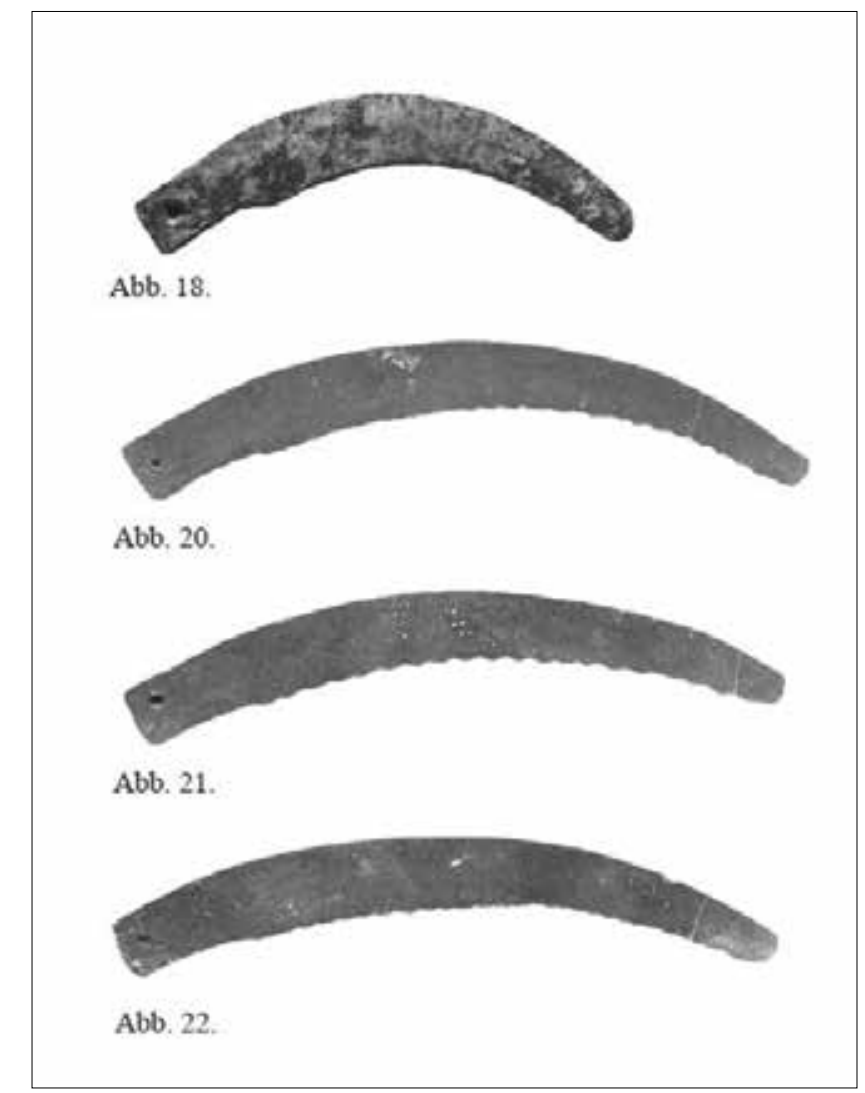

Figure 12: A group of Aegean-type curved knives from Aegina (after Gauss 2007, Abb. 18-22.) / Aegina'dan bir grup kavisli bıçak

\section{Transition From the Late Bronze Age to the Early Iron Age in and Around Tisna}

There is an array of evidence found throughout the inner Northern Aeolis territory, from the Çandarlı Bay to the Yunt Mountains, regarding the transition from the Late Bronze Age to the Early Iron Age. Early surveys along the coast from the south to the north and northwest within the bay provided findings that shed light on the second millennium BC in Şakran and Gryneion ${ }^{76}$. Despite the mentions regarding a find dating to the beginning of the second millennium $\mathrm{BC}$ in the early publications in Çaltıdere Höyük, which is situated just west of both settlements, new studies do not present any information about the Late Bronze Age ${ }^{77}$.

The presence of LH IIIA2-B pottery sherd in Elaia, further north along Çandarlı Bay, likely indicates that the Aegean effect was entering the region through the harbor and that Elaia was inhabited during the Late Bronze $\mathrm{Age}^{78}$. When moving from the bay to the west, the Mycenean stirrup jar in Pitane with pithos graves reveals the external effects in the LH IIIC period, similar to Elaia ${ }^{79}$.

\footnotetext{
76 Horejs 2014: 260-261.

77 Erdan 2017: 177.

78 Mellaart 1968: 188.

79 Özgünel 1983: 705.
}

Although the local Late Bronze Age pottery is found on the mounds along the Bakırçay Plain in the north of Pitane and Elaia, the only imported Mycenaean pottery belongs to a sherd of kylix from Atarneus in the northwestern part of the Dikili Bay ${ }^{80}$. Further north in Başantepe, it is reported that findings related to the second millennium $\mathrm{BC}$ were encountered ${ }^{81}$.

Findings dated to the Late Bronze Age are quite limited in the east of Tisna. When moving along the south east of Tisna, a Mycenaean piriform amphora ${ }^{82}$ left in a tomb in Çerkes Sultaniye in the Gediz Valley shows the limitedness of the samples. Although the amphora ${ }^{83}$ in question, which is dated to the LH IIIA2 periods, shows possible elite preferences in the region, it does not provide evidence of the Mycenaean existence. In the inner parts of the Gediz River; however, the Sardis settlement is located. While there is a small number of Mycenaean pottery in Sardis ${ }^{84}$, the only evidence of Aegean origin in the Kaymakç1 citadel in the north west is an Aegean-type knife ${ }^{85}$.

In the east of Tisna, despite the limited evidence in the interior, information is provided through safeguarded port cities in the southwest. At this point, it is seen that the bronze objects of Aegean origin came mainly from Panaztepe. Apart from different bronze objects (razor, spearhead, arrowhead) ${ }^{86}$, Aegean-type knives were found in Panaztepe ${ }^{87}$. In addition, if we exclude Troy in Western Anatolia, the presence of the weapon of Aegean origin in the northernmost part is a dagger, which is said to have come from Pergamon ${ }^{88}$. Although the origin of the sword is not absolutely reliable, when it is considered that it is located in Pergamon or its vicinity, it is possible to mention the largest known boundaries of the Mycenaean influence/presence along the Bakırçay-Gediz plain in the north.

As it has been mentioned before, the stirrup jar found in the grave in Pitane is dated to the LH IIIC period. While the stirrup jar in Pitane provides information about $\mathrm{LH}$ IIIC period activities extending to the north of Tisna, the $\mathrm{CO}$ tomb in Panaztepe ${ }^{89}$ in the west and southwest is dated to the LH IIIC period and it indicates that the Aegean-based tomb tradition was being carried out in the Hermos Plain ${ }^{90}$.

\footnotetext{
80 Pavuk/Horejs 2018: 469, 477, fig. 9.

81 Horejs 2014: 260.

82 French 1969: 52; Özgünel 1983: 739.

83 Özgünel 1983: 739.

84 Hanfmann 1983: 22-23.

85 Roosevelt et al. 2016: 246.

86 Ersoy 1988; Erkanal 2018: Taf. 346-359.

87 Ersoy 1988; Erkanal 2018: Taf. 346-348.

88 Sandars 1963: 140, Pl. 27.52.

89 Erkanal-Öktü 2008: 74, Fig. 7.

90 For chamber tombs in Mycenaean burial traditions. Ps.
} 
Since knobbed ware such as gritty ware in Tisna does not exhibit a feature of being a highly alluring commercial product, its existence must be related to the peoples who come to the settlement from the outside. The situation in question provides a general definition about the route, as well as a migration movement that reached the inner parts of Aeolis in the north-south direction during the transition to the Early Iron Age and the end of the Late Bronze Age. As it is known, previous research have pointed out that the pottery originating from the Balkans existed only in Panaztepe in Aeolis ${ }^{91}$.

The fact that such pottery was used in Troy VIIb3 until about $900 \mathrm{BC}^{92}$ manifests that migrations from Western Anatolia to the south possibly occurred intermittently. However, it is stated that knobbed ware is also associated with the Proto-Phrygian migration in Anatolia ${ }^{93}$. It is also observed that the pottery in question did not reach out of Anatolia ${ }^{94}$.

Handmade Burnished Ware ${ }^{95}$, which showed an increase in Greece in the early phase of LH IIIC after its first appearance in Crete ${ }^{96}$ in the first half of the 13th century $\mathrm{BC}$, was also obtained in Limantepe ${ }^{97}$ and Bademgediği Tepe $^{98}$. However, unlike knobbed ware, the spread of Handmade Burnished Ware went out of Anatolia and reached the East Mediterranean coasts and some centers in Cyprus and the Levant ${ }^{99}$.

On the other hand, regarding the transition from the Late Bronze Age to the Iron Age, it is possible to observe the continuity of the Protogeometric pottery in Pitane in Northern Aeolis region after LH IIIC pottery ${ }^{100}$. Although no other findings related to the Late Bronze Age are encountered in Kyme, south of Çandarlı Bay, Protogeometric pottery is obtained ${ }^{101}$. Further in the south, however, the encounter with Protogeometric pottery in Böcelitepe $^{102}$, in the northwestern part of Larisa, shows that a different impression was made than the existing Late Bronze Age settlements. At this point, the presence

Cavanagh/Mee 1998.

91 Çınardal1-Karaaslan 2008: 63; Erkanal-Öktü 2008: 80, Fig 13ac.

92 Rose 2011: 411; Hnila 2012: 17.

93 Muhly 2003: 28.

94 Lis 2009: 154, Fig. 18.2.

95 Rutter 1975; Lis 2009: 150-157; Rahmstorf 2011: 315-318, 323, Fig.5.

96 D'Agata/Boileau/De Angelis 2012: 299-300.

97 Erkanal 1999: 327, Fig. 3-4; Mangaloğlu-Votruba 2011: 50, 53, Fig. 4d.

98 Meriç/Öz 2015: 597, Fig. 6.

99 Badre 2006: 82-92; Charaf 2011: 203-205, Fig. 2-3; Romanos 2011: 31-32.

100 İren 2003: 31.

101 İren 2003: 31.

102 İren 2003: 31. of the pendent semi-circle skyphos fragment in Tisna, which is likely dated to the Sub-Protogeometric period, points out that the Aegean influences could enter the inner parts of the region with the end of the Protogeometric period. This condition also reveals the cultural continuity in the settlement.

\section{Conclusion}

The finds unearthed in Tisna, which is located in the easternmost part of the Northern Aeolis territory together with Aigai, reveal some ideas regarding the transition from the Late Bronze Age to the Early Iron Age, apart from the general knowledge about the region. As it is known, the findings related to the Late Bronze Age spread to the east and north coasts of the Çandarlı Bay and further up to the Dikili Bay. Some of this information can be obtained directly through Aegean origin finds.

It is possible to recommend the fragment of knife in Tisna within the Aegean-type with its thin curved feature. In the Aegean world, especially these type of knives were used in the last years of Mycenaean kingdoms and in the period after their destructions. The fact that these type of knives were very popular especially in the $12^{\text {th }}$ century $\mathrm{BC}$ in the Aegean geography gives rise to the thought about the accessibility of LH IIIC activities up to the highlands in the east of Bakırçay Plain. In Northern Aeolis, finds from the LH IIIC period, as is known, consist of only a stirrup jar with an octopus decoration found in Pitane ${ }^{103}$. As it can be seen from the examples, Aegean-type knives are obtained in the graves more frequently in the Aegean World, and this situation is more evident for Western Anatolia. In this respect, it is most plausible that the fragment of the knife unearthed in Tisna is related to a grave. All in all, the Aeolis lands from the north to the South, the external influences in the Late Bronze Age must indicate that the region does not have a conservative structure ${ }^{104}$.

The presence of gritty ware in a settlement south of Troy must probably be related to regional population movements during the Late Bronze Age. With this aspect, it is possible to suggest that a contribution was made to the connection between Troas and Aeolis lands in the Late Bronze Age with a find over Tisna. In the Late Bronze Age, we know from Hittite documents that the territory of Wilusa (which includes the Troas Region) and the territory of the Seha River Land (which includes the regions of Aeolis, the Bakırçay and the Gediz Plains) are borders ${ }^{105}$. At this point, the presence of a locally produced pottery, which was used in Troy, in

\footnotetext{
103 Özgünel 1983: 705.

104 Gür 2019: 1958.

${ }^{105}$ Bryce 2006. 86.
} 
the Bakırçay Basin should not be considered a surprise within the existing population movements ${ }^{106}$. However, only new findings that may emerge in the coming years will strengthen the interpretation.

The presence of knobbed ware in Troy VIIb2 ${ }^{107}$ may be seen as being related to the existence of a group moving from Troy and its surroundings or throughout the Balkans rather than its presence in the settlement as a direct commercial commodity. In previous studies, it was observed that the Balkan influence was limited to the coastal part of the Hermos plain, while Tisna surveys revealed that the Balkan effects extended from the shores of the Bakırçay Plain to the innermost parts in Northern Aeolis.

While Handmade Burnished Ware increased in the Aegean World in the LH IIIC Early phase, immigration activity extending to the Eastern Mediterranean continued in the same period. Knobbed Ware is generally dated to the VIIb2 phase (1130-1070/1040 $\mathrm{BC})^{108}$, and this period corresponds to the LH IIIC Middle phase in Aegean chronology. LH IIIC Middle phase refers to the period when the immigration mobility of the peoples of Aegean origin declined, long-lived settlements were established and the Mycenaean culture reflects the characteristics of the old days for the last time ${ }^{109}$.

As similar patterns of wave decorations on gray ware were seen in the Late Bronze Age, especially their close parallels dating to the Early Iron Age are found in Mytilene, Lesbos-Antissa and Phocaea. With this aspect, it is also possible to mention the existence of the local pottery tradition of the region in the transition to the Early Iron Age.

As mentioned before, Protogeometric pottery, which is limited only to Kyme and Pitane around Çandarlı Bay, displays that a relatively insufficient effect continued compared to the southern coastal part of Aeolis, like the Mycenaean influences in the Late Bronze Age. Despite the fact that a fragment of skyphos that can be dated to the Sub-Protogeometric period shows the traces of the Aegean origin in the settlement, it is important in terms of making a new contribution to the known borders of the Aegean influences from the coastal area to the mountainous area in the Aeolis region.

${ }^{106}$ It is known that slaves and prisoners of war escaped and took refuge in different countries in Hittite Anatolia. Beckman 1996: $78,83,86$.

${ }^{107}$ See footnote 25 .

108 Aslan et al. 2014: 277, Tab.1.

${ }^{109}$ Demakopoulou 2007: 168; Deger-Jalkotzy 2008: 406.
As a result, the mentioned finds in Tisna reveal supportive results in addition to the new and known ones regarding the transition from the Late Bronze Age to the Early Iron Age in Aeolis. It is thought that the archaeological excavations to be carried out in Tisna in the coming years will provide new evidence to support these findings. 


\section{REFERENCES}

ALLEN, S.H. 1991.

"Late Bronze Age Grey Wares in Cyprus", Cypriot Ceramics: Reading the Prehistoric Record (Eds. J.A. Barlow/D.L. Bolger/B. Kling), Philadelphia: 151-168.

\section{ALRAM-STERN, E. 2007.}

"Characteristic Small Finds of LH III C from Aigeira and their Context", LH IIIC Chronology and Synchronisms iI LH IIIC Middle, Proceedings of the International workshop held at the Austrian Academy of Sciences at Vienna October 29th and 30th, 2004 (Eds. S. DegerJalkotzy/M. Zavadil), Wien: 15-26.

\section{ALRAM-STERN, E/ JALKOTZY, S.D. 2006.}

Die österreichischen Ausgrabungen von Aigeira in Achaia, Aigeira I. Die mykenische Akropolis, Faszikel 3, Vormykenische Keramik. Kleinfunde. Archäozoologische und archäobotanische Hinterlassenschaften. Naturwissenschaftliche Datierung,Veröffentlichungen der Mykenischen Kommission 24. Sonderschriften des Österreichischen Archäologischen Institutes 43, Wien.

ASLAN, C. 2011.

"A Place of Burning: Hero or Ancestor Cult at Troy", Hesperia 80: 381-429.

ASLAN, C. 2019.

"Troy and the Northeastern Aegean", A Companion to the Archaeology of Early Greece and the Mediterranean, (Ed. I.Lemos/A. Kotsonas). WileyBlackwell: 939-959.

ASLAN, C/KEALHOFER, L/GRAVE, P. 2014.

"The Early Iron Age at Troy Reconsidered", Oxford Journal of Archaeology 33/3: 275-312.

ASLAN, C/HNILA, P. 2015.

"Migration and Integration at Troy from the End of the Late Bronze Age to the Iron Age”, Nostoi. Indigenous Culture, Migration and Integration in the Aegean Islands and Western Anatolia during the Late Bronze and Early Iron Age. Proceedings of the International Conference held in Istanbul 31 March - 3 April 2011 (Eds. K. Kopanias / Ç. Maner / N. Stampolidis). İstanbul: 185-210.

AYDINGÜN, Ş/AYDINGÜN, H. 2013.

"Erken Demirçağ'da İstanbul Boğazı Üzerinden Trak Frig Kavimlerinin Anadolu'ya Geçişine ait ilk bulgular”, Arkeoloji ve Sanat Dergisi 142: 65-78.
AYKURT, A. 2008.

"Batı Anadolu'da Gri Seramiğin Kökeni ve Gelișimi”, Batı Anadolu ve Doğu Akdeniz Geç Tunç Çağı Kültürleri Üzerine Yeni Araştırmalar, (Ed. A.ErkanalÖktü/S. Günel/U. Deniz). Ankara: 9-18.

BADRE, L. 2006.

"Tell Kazel-Simyra: A Contribution to a Relative Chronological History in the Eastern Mediterranean during the Late Bronze Age", Bulletin of the American Schools of Oriental Research 343: 65-95.

BECKMAN, G. 1996.

Hittite Diplomatic Texts. Atlanta.

BEKSAÇ, E. 2001.

"Balıkesir Illi, Ayvalık, Gömeç, Burhaniye, Edremit ve Havran Illçelerinde Pre-ve Protohistorik Yerleşmeler Yüzey Araştırması 1999”, 18. Araştırma Sonuçları Toplantısı 2, Ankara: 113-122.

BLEGEN， C.W/BOULTER， C.G/CASKEY， J.L/ RAWSON, M. 1958.

Troy Settlements VIIa, VIIb and VIII Vol.IV. part 1: Text. Princeton.

BOEHLAU, J/SCHEFOLD, K. 1942.

Larisa am Hermos III, Die kleinfunde, Berlin.

BOZHINOVA, E. 2012.

"Thrace Between East and West: The Early Iron Age Cultures in Thrace", Anatolian Irona Ages 7 The Proceedings of the Seventh Anatolian Iron Ages Colloquium Held at Edirne, 19-24 April 2010, (Eds. A. Çilingiroğlu/A. Sagona). Leuven-Paris-Walpole: 51-72.

BRYCE, T. 2006.

The Trojans and Their Neighbours, London-New York.

BURKE, B. 2005.

"Textile Production at Gordion and the Phrygian Economy", The Archaeology of Midas and the Phrygians: Recent Work At Gordion, (Ed. L. Kealhofer). Philadelphia: 69-81.

CATLING, H.W. 1964.

Cypriot Bronzework in the Mycenaean World, Oxford.

CATLING, H.W/CATLING E.A. 1981.

“'Barbarian' Pottery from the Mycenaean Settlement at the Menelaion, Sparta", The Annual of the British School at Athens 76: 71-82. 
CAVANAGH, W/MEE, C. 1998.

A Private Place: Death in Prehistoric Greece, Jonsered.

\section{CHARAF, H. 2011.}

"Over the hills and far away: Handmade Burnished Ware and Mycenaean cooking pots at Tell Arqa, Lebanon", On Cooking Pots, Drinking Cups, Loomweights and Ethnicity in Bronze Age Cyprus and Neighbouring Regions, An International Archaeological Symposium held in Nicosia, November 6th - 7th 2010, (Eds. V. Karageorghis/O. Kouka). Nicosia: 203-218.

COLDSTREAM, N. 2003.

Geometric Greece: 900-700 BC, London and New York.

CONZE, A. 1910.

"Eine Griechhische Stadt", JdI XXV: 1-12.

ÇINARDALI KARAASLAN, N. 2008.

"Panaztepe Liman Kentte Yapılan Son Çalışmalar", Batı Anadolu ve Doğu Akdeniz Geç Tunç Çağı Kültürleri Üzerine Yeni Araştırmalar, (Ed. A.Erkanal-Öktü/S. Günel/U. Deniz). Ankara: 57-68.

D'AGATA, A.L/BOILEAU, M.C/DE ANGELIS, S. 2012.

"Handmade Burnished Ware from the island of Crete: A view from the inside", Rivista di Scienze Preistoriche LXII: 295-330.

DEMAKOPOULOU, K. 2007.

"Laconia and Arcadia in LH III C Middle: Pottery and other Finds", LHIII C Chronology and Synchronisms II: LH IIIC Middle: Proceedings of the International Workshop Held at the Austrian Academy of Sciences at Vienna October 29th and 30th, 2004, (Eds. S. DegerJalkotzy/ M. Zavadil). Wien: 161-174.

DEGER-JALKOTZY, S. 2008.

"Decline, Destruction, Aftermath", The Cambridge Companion to The Aegean Bronze Age, (Ed. C.W. Shelmerdine), Cambridge: 387-415.

DICKINSON, O. 2007.

The Aegean From Bronze Age to Iron Age: Contiunity and Change Between the Twelfth and Eighth Centuries BC, Oxford.

DIEST, W. 1889.

Von Pergamon über den Dindymos zum Pontus.

ERDAN, E. 2017.

"Myrina-Gryneion Arasında Bir Höyük Yerleşimi: Çaltıdere Höyüğ̈̈ 2016 Yılı Araştırmaları”, Myrina ve Gryneion Arkeolojik Yüzey Araştırmaları: Belgeler ve Yeni Araştırmalar 1. Cilt, (Eds. M. Çekilmez/E. Dereboylu Poulan), İzmir: 177-184.

ERDAN, E/TIRO, A.O. 2018.

"Myrina Territoriumundan Bir Arkeolojik Yerleşim: Tisna (Tisna?)", Myrina ve Gryneion Arkeolojik Yüzey Araştırmaları: Son Araştırmalar ve Disiplinler Arası Çalışmaları, (Eds. M. Çekilmez/E.Dereboylu Poulan), İzmir: 111-126.

ERDAN, E/GÜR, B. 2018.

"Myrina'nın Güzergahı: Bir Çıkmaz Sokak Olarak "Aiol Göç Efsanesi" ve Aiolis-Doğu Akdeniz Bağlantıları", Myrina ve Gryneion Arkeolojik Yüzey Araştırmaları: Son Araştırmalar ve Disiplinler Arası Çalış̧aları, (Eds. M. Çekilmez/E.Dereboylu Poulan), İzmir: 403440.

ERDAN, E. 2019.

Tisna I: İlk Araştırmalar ve Gözlemler, İstanbul.

ERKANAL, H. 1999.

"1997 Liman Tepe Kazıları", 20. Kazı Sonuçları Toplantısı 1, Ankara: 325-336.

ERKANAL ÖKTÜ, A. 2008.

"The Late Bronze Age Cemeteries of Panaztepe", Batı Anadolu ve Doğu Akdeniz Geç Tunç Çağı Kültürleri Üzerine Yeni Araştırmalar, (Ed. A.Erkanal-Öktü/S. Günel/U. Deniz), Ankara: 69-90.

ERKANAL ÖKTÜ, A. 2018.

Panaztepe I: Die Friedhšfe von Panaztepe Text-Tafeln. Ankara.

ERSOY, Y. 1988.

"Finds from Menemen/Panaztepe in the Manisa Museum", Annual of the British School at Athens 83: 55-82.

FRENCH, D.H. 1969.

"Prehistoric Sites in Northwest Anatolia: II. The Ballkesir and Akhisar/Manisa Areas", Anatolian Studies 19: 4198.

GAUSS, W. 2007.

"Prähistorische Funde vom Gipfel des Oros auf Ägina", Stephanos Aristeios. Archäologische Forschungen zwischen Nil und Istros; Festschrift für Stefan Hiller zum 65. Geburtstag, (Eds. F. Lang/C. Reinholdt/J. Weilhartner). Wien: 125-142.

GENCER, N. 2006.

"Sarımeşe Tepe Madeni Buluntularl", Hayat Erkanal'a Armagan. Kültürlerin Yansıması / Studies in Honor of Hayat Erkanal. Cultural Reflections, İstanbul: 373-378. 
GUZOWSKA, M/ KULEFF, I/PERNICKA E/SATIR, M. 2003.

"On the Origin of Coarse wares", Troia and the Troad: Scientific Approaches, (Eds. G.A. Wagner/E. Pernicka/ H.P. Uerpmann), Heidelberg: 233-249.

GÜR, B. 2014.

Miken Uygarlı̆̆ı ve Ahhiyawa, İstanbul.

GÜR, B. 2019.

“Geç Tunç Çağl’nda Aiolis ve Yakın Çevresinin Ortak Kültürel Dinamikleri ve Bölgenin Ege Dünyası ile İlişkilerinde Yerel Unsurlar”, History Studies 11/6: 1947-1967.

HANFMANN, G.M.A/GEORGE, M.A. 1983.

Sardis From Prehistoric to Roman Times: Results of the Archaeological Exploration of Sardis 19581975, London.

HNILA, P. 2011.

Pottery of Troy VIIb. Chronology, classification, context and implications of Trojan ceramic assemblages in the Late Bronze Age/Early Iron Age transition, Dissertation zur erlangung des akademischen grades Doktor der Philosophie in der Philosophischen Fakultät der Eberhard Karls Universität Tübingen.

HOREJS, B. 2014.

"The 2nd Millenium BC in the Baktrcay (Kaykos) Valley. An Overview", Armağan Erkanal'a Armağan. Anadolu Kültürlerine Bir Bakış / Compiled in Honor of Armağan Erkanal. Some Observations on Anatolia Cultures, (Eds. N. Çınardalı-Karaaslan/A. Aykurt/N. KolankayaBostanc1/Y. H. Erbil), Ankara: 257-274.

İREN, K. 2008.

"Dark Age Pottery From Southern Aeolis, A New Dawn for the Dark Age?", Shifting Paradigms in Mediterranean Iron Age Chronology, L'âge obscur se fait-il jour de nouveau? Les paradigmes changeants de la chronologie de l'âge du Fer en Méditerranée, (D. Brandherm/Trachsel, M.). Oxford: 29-43.

LASZLO, A. 1996-1997.

"Troy and the lower Danube region at the end of the Bronze Age", Studia Antiqua et Archaeologica, 3/4, 1996/97: 50-60.

LEMOS, I. 2002.

The Protogeometric Aegean: The Archaeology of the Late Eleventh and Tenth Centuries BC. Oxford.
LIS, B. 2009.

"Handmade and Burnished pottery in the eastern Mediterranean at the end of the bronze age - Towards an explanation of its diversity and geographical distribution", Forces of Transformation: The End of the Bronze Age in the Mediterranean : Proceedings of an International Symposium Held at St. John's College, University of Oxford 25-6th March, 2006, (Eds. C. Bachhuber/R.G. Roberts). Oxbow: 150-161.

LOLOS, Y.G. 2003.

"Cypro-Mycenaean Relations ca. 1200 BC: Point Iria in the Gulf of Argos and Old Salamis in the Saronic Gulf", Ploes ... Sea Routes ... Interconnections in the Mediterranean 16th-6th C. bc: Proceedings of the International Symposium Held at Rethymnon, Crete, September 29th-October 2nd 2002, (Eds. N.C. Stampolidis/V. Karageorghis). Athens: 101-115.

MANGALOĞLU-VOTRUBA, S. 2011.

"Liman Tepe'de Geç Hellas IIIC Dönemi", Anatolia 37: 43-73.

MELLAART, J. 1968.

"Anatolian Trade with Europe and Anatolian Geography and Culture Provinces in the Late Bronze Age", Anatolian Studies 18: 187-202.

MERIÇ, R/ÖZ, A.K. 2015.

"Bademgediği Tepe (Puranda) Near Metropolis," Nostoi. Indigenous Culture, Migration and Integration in the Aegean Islands and Western Anatolia during the Late Bronze and Early Iron Age. Proceedings of the International Conference held in Istanbul 31 March - 3 April 2011 (Eds. K. Kopanias / Ç. Maner / N. Stampolidis). İstanbul: 609-626.

MUHLY, J. 2003.

"Greece and Anatolia in the Early Iron Age: The Archaeological Evidence and the Literary Tradition", Symbiosis, Symbolism, and the Power of the Past: Canaan, Ancient Israel, (Eds. W.G. Dever/S. Gitin). Winona Lake: 23-35.

ÖZDOĞAN, M. 1987.

"Taşlicabayır, A Late Bronze Age Burial in Eastern Thrace”, Anatolica XIV: 5-39.

ÖZDOĞAN, M. 1993.

"The Second Millenium of the Marmara Region", Istanbuler Mitteilungen 43: 151-163.

ÖZDOĞAN, M. 2011.

"Eastern Thrace: The Contact Zone between Anatolia and the Balkans", The Oxford Handbook of Ancient 
Anatolia: (10,000-323 BCE), (Eds. G. McMahon/S. Steadman). Oxford: 657-682.

ÖZGÜNEL, C. 1983.

"Batı Anadolu ve içerlerinde Miken etkileri", Belleten XLVII: 697-743.

PASCHALIDIS, C. 2018.

The Mycenaean Cemetery at Achaia Clauss near Patras: People, material remains and culture in context. Oxford.

PASCHALIDIS, C/MCGEORGE, P.J.P. 2009.

"Life and death in the periphery of the Mycenaean world at the end of the Late Bronze Age: The case of the Achaea Klauss cemetery" From the Aegean to the Adriatic, Social Organizations Modes of Exchange and Interaction in the Postpalatial Times (12th-11th BC), Acts of the International Seminar, Udine, 1-2 December 2006, (Eds. Borgna, E/P. Càssola Guida). Roma: 79-113.

PAVUK, P. 2014.

Troia VI Früh und Mitte. Keramik, Stratigraphie, Chronologie, Studia Troica Monographien 3. Bonn.

PAVUK, P/HOREJS, B. 2018.

"Ceramics, Surveys, and Connectivity in Western Anatolia: The Middle and Late Bronze Age Bakirçay/ Kaikos Valley Restudied”, Ägypten und Levante XXVIII: 457-486.

PETROPOULOS, M. 2007.

"A Mycenaean Cemetery at Nikoleika near Aigion of Achaia”, LH IIIC Chronology and Synchronisms iı LH IIIC Middle, Proceedings of the International workshop held at the Austrian Academy of Sciences at Vienna October 29th and 30th, 2004, (Eds. S. DegerJalkotzy/ M. Zavadil). Wien: 253-286.

PIENIAZEK, M/PAVUK, P/KOZAL, E. 2018.

"The Troad, South Aegean, and the Eastern Mediterranean. Long-Distance Connections during the Middle and Late Bronze Age", Bronzezeitlicher Transport: Akteure, Mittel und Wege, (Eds. B. Nessel/ D. Neumann/M. Bartelheim). Tübingen: 375-410.

PINTER, F. 2005.

Provenance study of the Early Iron Age Knobbed ware in Troia, NW Turkey and the Balkans. Petrographic and geochemical evidence, Dissertation zur Erlangung des Grades eines Doktors der Naturwissenschaften der Geowissenschaftlichen Fakultät der Eberhard-KarlsUniversität Tübingen.
RAHMSTORF, L. 2011.

"Handmade pots and crumbling loomweights: 'Barbarian' elements in the eastern Mediterranean in the last quarter of the 2nd millennium BC', On Cooking Pots, Drinking Cups, Loomweights and Ethnicity in Bronze Age Cyprus and Neighbouring Regions, An International Archaeological Symposium held in Nicosia, November 6th - 7th 2010, (Eds. V. Karageorghis/O. Kouka). Nicosia: 315-330.

REINACH, S. 1885.

“Chronique d'Orient”, Revue Archéologique 1885: 87116.

RIGTER, W.E. 2013

Die Tan Ware innerhalb des Keramikspektrums des spätbronzezeitlichen Troia, Dissertation zur Erlangung des akademischen Grades Doktor der Philosophie in der Philosophischen Fakultät der Eberhard Karls Universität Tübingen, Amsterdam.

ROMANOS, C.L. 2011.

Handmade Burnished Ware in Late Bronze Age Greece and its makers, A thesis submitted to The University of Birmingham for the degree of Doctor of Philosophy, Institute of Archaeology and Antiquity The University of Birmingham.

ROMIOPOULOU, K. 1971.

"Some Pottery of the Early Iron Age from Western Macedonia", The Annual of the British School at Athens 66: 353-361.

ROOSEVELT, C.H/LUKE, C/ÜNLÜSOY, S. 2016.

"Kaymakçı Arkeoloji Projesi: 2014 Yılı Kazı Sonuçları", 37. Kazı Sonuçları Toplantısı 2, Ankara: 243-268.

RUTTER, J. 1975.

"Ceramic Evidence for Northern Intruders in Southern Greece at the Beginning of the Late Helladic IIIC Period", American Journal of Archaeology 79/1: 1732.

SAMS, G.K. 1992.

"Observations on Western Anatolia", The Crisis Years: The 12th Century B.C. From Beyond the Danube to the Tigris, (Eds. W.A. Ward/M. Joukowsky). DubuqueIowa: 56-60.

SANDARS, N.K. 1955.

"The Antiquity of the One-edged Bronze Knife in the Aegean”, The Prehistoric Society 20: 174-197.

SANDARS, N.K. 1963.

"Later Aegean Bronze Swords", American Journal of Archaeology 67/2: 117-153. 
SAYCE, A.H. 1882.

"Explorations in Aeolis", The Journal of Hellenic Studies 3: 218-227.

SAZCI, G. 2012.

"Maydos Kilisetepe Höyüğ̈̈", Arkeoloji ve Sanat Dergisi 140: 13-20.

SCHUCHHARDT, C. 1887.

"Vorläufiger Bericht über eine Bereisung der pergamenischen Landschaft", Sitzungsberichte der Koeniglich Preussischen Akademie der Wissenschaft zu Berlin: 1207-1214.

VASSILEVA, M. 2005.

"Phrygia, Troy and Thrace", Anatolian Iron Ages 5: Proceedings of the Fifth Anatolian Iron Ages, (Eds. A. Çilingiroğlu/G. Darbyshire), London.

VERDAN, S/KENZELMANN, P/THEURILLAT, T. 2014.

"Euboean Pottery from Early Iron Age Eretria in the Light of the Neutron Activation Analysis", Archaeometric analyses of Euboean and Euboean related pottery: New results and their interpretations, Proceedings of the Round Table Conference held at the Austrian Archaeological Institute in Athens, 15 and 16 April 2011, (Eds. M. Kerschner/I.S. Lemos), Wien: 71-90.

VERGER, S. 2014.

"Kolophon et Polieion À propos de quelques objets métalliques archaïques de Policoro", Siris 14: 15-41.

WACE, J.B. 1953.

"Mycenae, "1939-1952: Part I. Preliminary Report on the Excavations of 1952", The Annual of the British School at Athens 48: 1-18.

YALÇIN, Ü/PULAK, C/SLOTTA, R. 2006.

Uluburun Gemisi 3000 Yıl Önce Dünya Ticareti. Bochum. 